\title{
RHETORIC OF ADVERTISING INFLUENCE
}

\section{Shcherbak O. V.}

\section{INTRODUCTION}

Today the scientific observation of the phenomenon of advertising influence covers many research platforms, including sociology (T. Bulakh, N. Furmankevich, Yu. Shmyga, L. Teodorska, O. Zimina,), psychology (I. Agapova, D. Dontsov, O. Hordyakova, O. Lebedev, V. Zazykin), economics (N. Borden, F. Kotler, J.-K. Larresche, I. Vinnikova, R. Wale, T. Yakovenko), public administration (V. Kiriyakova, S. Khudar, Ye. Romat), art history (P. Huzenko, A. Vuyma, S. Zarya), culturology (B. Matviychuk), design (M. Murashko), philosophy (Yu. Yuvkovetska). However, in the Eastern European scientific space the leading center of research of advertising influence is a branch of linguistics. In its space the relevant studies were first made possible by the tools of suggestive linguistics (Ye. Anikin, I. Bohdanova, I. Cherepanova, N. Chumichova, O. Horyachev, S. Romanyuk, O. Tolkunova, V. Zirka) and neurolinguistic programming or NLP (T. Kovalevska, I. Avdeyenko, R. Khalimova, A. Kovalevska, O. Oleksyuk, Yu. Stankevich). The provisions of pragmatic linguistics (G. Atakyan, I. Balabanova, Yu. Bulyk, A. Chernova, I. Horodetska, K. Ivanova, H. Karimova, L. Kirichuk, M. Kramarenko, N. Kruvko, A. Makedontseva, O. Makedonova, K. Maksimenko, I. Murog, I. Negovorova, O. Popova, O. Pochtar, A. Segal, D. Sknarev, A. Vornachev, F. Yan), communicative linguistics (O. Areshenkova, O. Hasparyan, I. Kovalchuk, N. Kondratenko, O. Sokolova, I. Shukalo), cognitive linguistics (T. Chernyshova, O. Olenyuk, V. Okhrimenko, V. Samarina, T. Smirnova), psycholinguistics (V. Buryakovska， N. Kutuza，P. Mahnin, N. Shchennikova, M. Slavinska, A. Yampolsky) and others are also relevant for solving the outlined problems. Recently advertising influence has been sporadically studied in the linguosemiotic paradigm (G. Baeva, Yu. Kononets, T. Krutko, N. Lysa, N. Parshuk, M. Pchelintseva). The precondition for this scientific research is the fact that "two or more meanings can be assigned to one language form and, on the other hand, one meaning... can be expressed by several language forms" ${ }^{\prime 1}$. This property is a

${ }^{1}$ Issers O.S. (2011). Rechevoye vozdeystviye [Speech influence]. Moscow: Flint: Science (in Russian), p. 41. 
primarily characteristic of the rhetorical tools. The general issues of their functioning in advertising discourse have been successfully covered in the works of foreign (M. Lee, J. Linghong, E. McQueer, D. Mick, M. Salda, J. Weizinonien) and domestic (O. Areshenkova, O. Dubenko, I. Horodetska, I. Ivanova, V. Zirka) scientists. The problem of linguistic representation of rhetorical means of commercial advertising, taking into account their influential nature, is partly investigated on the materials of Russian (H. Atakyan, O. Horyachev, Ts. Zhu), English (O. Horyachev, S. Romanyuk, D. Terkulova, Ya. Yakub), German (H. Kudlynska-Stempen, O. Leshchenko, V. Samarina) and French (N. Kruvko) contexts. However, the systematization and scientific qualification of rhetorical tools of Ukrainian commercial television advertising, involving the latest research practices of suggestive linguistics, neurolinguistic programming and linguosemiotics, has not yet taken place. It fully meets the needs of the modern scientific matrix, because of the lack of semiotic and suggestive studies.

\section{Influence and its various types in advertising}

Today advertising and advertising discourse are fully "relevant factual array for the study of influential phenomena". It is confirmed by the dissertations of T. Kovalevska, V. Zirka, I. Bohdanova, I. Horodetska, A. Kovalevska, L. Ilnytska, N. Kutuza, O. Olenyuk, S. Romanyuk, A. Segal, Yu. Stankevich, Yu. Shmyga and others. However, S. Johnson was one of the first to draw attention to the ability of advertising to influence, devoting a note to this issue in the magazine "The Idler" in $1761^{3}$.

Influence is a polysemantic concept. It is often used in psychology, economics, political science, philosophy and linguistics. Taking a wider view, it means primarily "the action that a person or object or phenomenon manifests in relation to another person or object" 4 . In addition, there are narrower interpretations. $\mathrm{H}$. Bal and $\mathrm{M}$. Burgin claim that "the influence of object $\mathrm{B}$ on object $\mathrm{A}$ is an event in which the object $\mathrm{B}$ (possibly together with objects $\mathrm{C}, \mathrm{D}$ and others) causes or prevents some change in object $\mathrm{A} " 5$.

2 Kovalevska T. Yu. (2008). Komunikatyvni aspekty neyrolinhvistychnoho prohramuvannya [Communicative aspects of neurolinguistic programming]. Odesa: Astroprint (in Ukrainian), p. 232.

${ }^{3}$ Goddard A. (1998). The Language of Advertising. London - New York: Routledge (in English), p. 8.

4 Bilodid I. K. (1980). Slovnyk ukrayinskoyi movy [Dictionary of the Ukrainian language]. Kyiv: Naukova Dumka. V. 1, p. 751.

5 Ball G. A., Burgin M. S. (1994). Analiz psikhologicheskikh vozdeystviy i yego pedagogicheskoye znacheniye [Analysis of psychological influences and its pedagogical significance]. Psychology, no. 4, p. 56-66, p. 57. 
It means that they emphasize that the consequence of influence is necessarily a change of someone / something. L. Skibinska considers that the definition above is sufficient and adds that influence is "any behavior of one person that changes the behavior, attitudes, feelings, etc. of another person"6. However, these definitions are formulated in one way or another on the basis of a review of shamanic rituals of Egypt, Syria, Sumer, ritual songs, Buddhist mantras, biblical texts, Orthodox prayers. They became "the roots

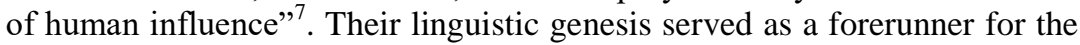
consideration of language as the main instrument of influence (J. Dzialoshinsky, L. Murzin), thanks to which the theory of influence became "an interdisciplinary branch, a component of which is the theory of speech influence" .

According to O. Selivanova, "studies of speech influence date back to ancient Greek rhetoric", which were based primarily on the rules of logic and persuasion ${ }^{10}$. J. Sternin thinks that not only rhetoric is the theoretical and methodological basis of modern understanding of speech influence, which in most cases is defined as "speech communication, taken in terms of its purposefulness, motivational conditionality, planned effectiveness"11. The researcher adds business communication and advertising as a science of effective promotion of goods on the market (in its textual, linguistic component $)^{12}$. However, even in this case, the researcher gives the primary role of rhetoric and assures that "with a broad understanding of it, it includes both interpersonal and business communication"13. In addition, the researcher rightly notes that "advertising influence is undoubtedly mainly in the field of the science of speech influence, because it is related to the text; however, the advertising impact also provides a technical side - graphics,

${ }^{6}$ Skibiltsa L. I. (2009). Liderstvo ta styl roboty menedzhera [Leadership and style of work of the manager]. Kyiv: Knyha (in Ukrainian), p. 9.

7 Kovalevska A. V. (2017). Suhestiya ta suhestyvni teksty: vytoky i spetsyfika [Suggestion and suggestive texts: origins and specifics]. Odeska linhvistychna shkola: $u$ prostorakh interpretatsiy [Odessa Linguistic School: in the spaces of interpretations]. Odessa: PolyPrint, p. 239-247, p. 239.

${ }^{8}$ Selivanova O. O. (2008). Suchasna linhvistyka: napryamy ta problem [Modern linguistics: directions and problems]. Poltava: Environment. Kyiv (in Ukrainian), p. 569.

${ }^{9}$ Ibid., p. 693.

${ }^{10}$ Sternin I. A. (2015). Osnovy rechevogo vozdeystviya [Fundamentals of speech influence]. Moscow - Berlin: Direct Media (in Russian), p. 6.

${ }^{11}$ Issers O. S. (2011). Rechevoye vozdeystviye [Speech influence]. Moscow: Flint: Science (in Russian), p. 20.

12 Sternin I. A. (2015). Osnovy rechevogo vozdeystviya [Fundamentals of speech influence]. Moscow - Berlin: Direct Media (in Russian), p. 4-5.

${ }^{13}$ Ibid., p. 5. 
design, visual aids, etc... By these aspects, advertising goes beyond the speech influence" ${ }^{14}$. This statement became the basis for the interpretation of advertising and advertising discourse as "a complex communicative phenomenon associated not only with the generation of the advertising text, but also placed in a complex relationship with a number of extralinguistic factors - knowledge of the world, intentions, guidelines and specific goals of the creator of the discursive space and the recipient of this discourse" 15 (M. Alekseeva, Ye. Anikin, N. Bilousova, S. Huzenko, T. Tarasevich, O. Tkachuk-Miroshnichenko, N. Walter). Therefore, in scientific practice the approach to the consideration of the influential potential of advertising with the operation of a broader concept - "communicative influence" has become traditional.

Communicative influence should be considered as "a complex conglomeration of emotionally charged verbal-nonverbal factors that correct the emotional (and rational) state of the individual or create a motivational basis for its programmed activities, which reduces the criticality, logic and objective assessment of perception, and also certain emotional, behavioral strategies of the personality that influence neurophysiological states are artificially modeled"16. It follows that this definition points to a few facts. Firstly, the advertising discourse with its inherent influence is not only a communicative event, but also a rhetorical act, because "emotionally charged factors" are primarily tools of rhetoric ${ }^{17}$. Secondly, the nature of communicative influence is heterogeneous (I. Cherepanova, O. Issers, V. Karasyk, A. Kiselyova, A. Kovalevska, T. Kovalevska, N. Kutuza, O. Leontiev, J. Sternin, Yu. Stankevich) with "triune mechanics"18. The first group of factors is the "psychological (psychomental) properties of person,

${ }^{14}$ Sternin I. A. (2015). Osnovy rechevogo vozdeystviya [Fundamentals of speech influence]. Moscow - Berlin: Direct Media (in Russian), p. 6.

${ }^{15}$ Alekseeva M. S. (2009). Pretsendentnyye fenomeny $v$ internet-reklame predpriyatiy restorannogo biznesa [Precedent phenomena in the Internet advertising of restaurant business enterprises] : (PhD Thesis), Nizhny Tagil: Nizhny Tagil State Pedagogical University, p. 47.

${ }^{16}$ Kovalevska A. V. (2017). Suhestiya ta suhestyvni teksty: vytoky i spetsyfika [Suggestion and suggestive texts: origins and specifics]. Odeska linhvistychna shkola: $u$ prostorakh interpretatsiy [Odessa Linguistic School: in the spaces of interpretations]. Odessa: PolyPrint, p. 239-247, p. 240.

${ }^{17}$ Zirka V. V. (2005). Yazykovaya paradigma manipulyativnoy igry $v$ reklame [The language paradigm of a manipulative play in advertising] : (Doctor Thesis), Dnepropetrovsk: Dnepropetrovsk National University, p. 83.

18 Kovalevska T. Yu. (2008). Komunikatyvni aspekty neyrolinhvistychnoho prohramuvannya [Communicative aspects of neurolinguistic programming]. Odesa: Astroprint (in Ukrainian), p. 182. 
determined by the peculiarities of deep correlative relationships at the levels of intersocial and interpersonal interactions, as well as in the segment of intrapersonal reflections" ${ }^{\prime 19}$. The second group is represented by the "neurophysiological characteristics of personality, described in the theory of interhemispheric asymmetry of the brain. Its integrative activity is provided by two systems: sensory perception system (right hemisphere psyche) and system of symbolic description of the environment in natural language elements (left hemisphere), which have a simultaneous-successive nature of mental activity" 20 . The third group contains the factors that determine "the specificity of psychosemantic and general semiotic characteristics of situational contexts, as well as their information structure (canceling, pretending, indefinite transformations), which are most pronounced in discourses with immanent suggestibility" 21 .

Addressing the question of determining the components of communicative influence, it is advisable to focus primarily on the works of A. Baranov, V. Zazykin, O. Leontiev, J. Sternin, T. Chmut, G. Chaika, M. Lukashevich, I. Osechynska, O. Shelestyuk. The models of this phenomenon with certain differences in quantitative and semantic indicators are presented in the research of these scientists. Therefore, T. Kovalevska synthesized their views and determined 4 fundamental components of influence. These are 1) properties of the suggestor (high social status and rating, intellectual and characterological superiority); 2) characteristics of the suggerend; 3) the relationship between them, which are based on trust in the influencer, 4) the method of constructing the message, that is, the actual language level of the discourse in the projection on the specifics of its information representation ${ }^{22}$.

The typology of communicative influence is considered to be practically an undeveloped problem today ${ }^{23}$, although much has been done to fill this lacunar segment of the research area. In particular, scientists distinguish the

19 Kovalevskaya T. Yu. (2014). Milton-model yak suchasna neyrolinhvistychna tekhnolohiya doslidzhennya movlennyevoho vplyvu [Milton model as a modern neurolinguistic technology for the study of speech influence]. Odeska linhvistychna shkola: intehratsiya pidkhodiv [Odessa Linguistic School: integration of approaches]. Odesa: Publisher Bukaev Vadym Viktorovych, p. 346-358, p. 348.

${ }^{20}$ Ibid., p. 348.

${ }^{21}$ Ibid., p. 349.

${ }^{22}$ Kovalevska T. Yu. (2014). Aktualni napryamy doslidzhennya verbalnoyi suhestiyi [Actual directions of research of verbal suggestion]. Odeska linhvistychna shkola: $u$ intehratsiya pidkhodiv [Odessa Linguistic School: integration of approaches]. Odesa: Publisher Bukaev Vadym Viktorovych, p. 323-331, p. 324.

${ }^{23}$ Selivanova O. O. (2008). Suchasna linhvistyka: napryamy ta problem [Modern linguistics: directions and problems]. Poltava: Environment. Kyiv (in Ukrainian), p. 697. 
following varieties: 1) direct and indirect; 2) overt and covert $(\text { H. Sokolova })^{24}$; 3) verbal and nonverbal, 4) monologue and dialogic ${ }^{25}$; 5) individual and group, 6) adequate and inadequate, 7) contact and distant; 8) suggestion and self-suggestion ${ }^{26}$;9) proof, persuasion, suggestion, order, request, coercion $(\mathrm{J} . \text { Sternin })^{27}$; 10) social, influence through artistic images, information, proof, argumentation, introduction, simulated dialogue, persuasion, appeal, command, coercion, evaluation, emotional influence, mental programming (L. Fedorova, O. Shelestyuk) ${ }^{28}$; 11) safe (information, persuasion and dialogue); relatively safe (managing the communicative situation, the use of provocative statements and actions, the use of fictitious figures and other forms of mimicry, social responsibility technology); dangerous (misinformation technologies, pseudo-technological technologies, psychological manipulation, psychological violence); highly dangerous (technologies of social induction, suggestive technologies and NLP) (J. Dzialoshynsky) ${ }^{29}$; 12) infection, wilting, persuasion (B. Parigin); 13) informing, instructing, stimulating (V. Olshansky); 14) persuasion, selfpromotion, suggestion, infection, awakening of the impulse of imitation, formation of attachment, request, coercion, destructive criticism, manipulation (E. Sidorenko); 15) suggestion, request, persuasion, bribery, threat, order (P. Melnyk) ${ }^{30}$ etc.

T. Kovalevska notes that the commercial advertising, which is the object of our study, "is based on suggestive mechanisms. They focus on the right hemisphere, influence the guidelines of the individual and community and

${ }^{24}$ Sokolova G. (2014). Vidy rechevogo vozdeystviya na kommunikanta [Types of speech impact on the communicant]. The word in the context of time. T. 1. Minsk: Belarusian State University, p. 388-392.

${ }^{25}$ Navasartyan L. G. (2017). Yazykovyye sredstva i rechevyye priyemy manipulyatsii informatsiyey $v$ SMI (na materiale rossiyskikh gazet) [Language tools and speech techniques for manipulating information in the media (based on Russian newspapers)] : (PhD Thesis), Saratov: Saratov State University, p. 11-13.

${ }^{26}$ Ibid., p. $142-143$.

27 Sternin I. A. (2015). Osnovy rechevogo vozdeystviya [Fundamentals of speech influence]. Moscow - Berlin: Direct Media (in Russian), p. 81-83.

28 Tolkunova E. G. (1998). Semanticheskoye opisaniye sovremennykh russkikh reklamnykh tekstov (suggestologicheskiy aspekt) [The semantic description of modern Russian advertising texts (suggestological aspect)] : (PhD Thesis), Barnaul: Barnaul State University, p. 58-59.

${ }^{29}$ Dzyaloshinsky I. M. (2012). Kommunikativnoye vozdeystviye: misheni, strategii, tekhnologii [Communicative impact: targets, strategies, technologies]. M. : HSE (in Russian), p. 79.

30 Kuzmin O., Kolinko N. (2013). Metody vplyvu yak efektyvnyy instrument kerivnoyi innovatsiynoyi [Methods of influence as an effective tool of leading innovative activity] Visnyk of Ternopil National University of Economics, vol. 2, p. 71-80. 
accordingly reduce the logical element of perception, causing holisticintuitive decoding of messages" ${ }^{31}$. Therefore, we have reason to say that the Ukrainian commercial television advertising also has a suggestive orientation, and therefore, among all the variety of types of communicative influence of further concretization needs the concept of suggestion.

Suggestion is "the process of influencing the mental sphere of person, associated with a decrease in criticality in the perception and implementation of the suggested content" ${ }^{\prime 2}$. This is confirmed by the analytical conclusions of scientists (V. Zazykin, V. Zirka, A. Kovalevska, L. Navasartyan, Yu. Stankevich, V. Stepanov, O. Tolkunova). This type of influence also "ensures the launch of subconscious programs, through which the human psyche and / or physiology must obey, finding in the external environment ways to perform the suggested tasks" $" 33$.

According to their suggestive effect, advertising texts are not identical, because "different people have different degrees of suggestion, level of susceptibility to suggestion, subjective readiness to feel the suggested influence and succumb to it" ${ }^{34}$. V. Zazykin notes that the implementation of the suggestive influence on the recipient of advertising contribute to both personal (insecurity, anxiety, timidity, low self-esteem, feelings of inferiority, increased emotionality, vulnerability, weakness of logical analysis) and situational (mental) states (calm, relaxation, stress, fatigue, disease), low level of awareness, high significance of the product / service, uncertainty, lack of time) factors ${ }^{35}$. The main task of suggestive influence in advertising, as stated by O. Tolkunova, is to create images of the product and the addressee with a plus factor, as well as the use of stereotypical ideas in a new context ${ }^{36}$. Achieving these goals is possible primarily due to the specificity and imagery of the keywords of the advertising text, the specificity and imagery of the advertised product, the absence of "no" in the

31 Kovalevska T. Yu. (2008). Komunikatyvni aspekty neyrolinhvistychnoho prohramuvannya [Communicative aspects of neurolinguistic programming]. Odesa: Astroprint. (in Ukrainian), p. 210.

${ }^{32}$ Petryk B. M. (2011). Suhestyvni tekhnolohiyi manipulyatyvnoho vplyvu [Suggestive technologies of manipulative influence]. Kyiv: CJSC "VIPOL" (in Ukrainian), p. 43.

33 Shelestyuk E. V. (2014). Rechevoye vozdeystviye: ontologiya $i$ metodologiya issledovaniya [Speech influence: ontology and research methodology]. Moscow: FLINT: Nauka (in Russian), p. 51-52.

34 Zazykin V. G. (1992). Psikhologiya v reklame [Psychology in advertising]. Moscow: DataStrom (in Russian), p. 25.

${ }^{35}$ Ibid., p. 25-26.

${ }^{36}$ Tolkunova E. G. (1998). Semanticheskoye opisaniye sovremennykh russkikh reklamnykh tekstov (suggestologicheskiy aspekt) [The semantic description of modern Russian advertising texts (suggestological aspect)] : (PhD Thesis), Barnaul: Barnaul State University, p. 34-35. 
advertising text, speech and nonverbal dynamics of advertising, the use of certain sounds $^{37}$, etc. We add that suggestive mechanisms of influence in advertising "under certain conditions can become manipulative" ${ }^{38}$. However, they in no way eliminate its suggestive core.

Consider this on the example of such linguosemiotic components of advertising as rhetorical codes.

\section{Rhetorical codes of advertising: semiotic polymanism}

The concept of "rhetorical code" in the terminological apparatus of linguosemiotics has a broad and narrow interpretation. In a broad sense it is defined by U. Eco and interprets it as "established stylistic figures and formulas" 39 . This definition actually represents the identification of the rhetorical code with the stylistic figure and the path, which diffuses the semantic amplitude of the term. R. Bart gives a narrow understanding of the rhetorical code and considers it as"a field of associations caused by certain rhetorical figures" ${ }^{40}$. Such a comprehensive approach is generally supported in the works of V. Stepanov. But the researcher's definition has a purely pragmatic orientation, because, in his opinion, the rhetorical code consists of two subcodes - emotionally expressive means (traditional tropes and figures of speech) and speech genres ${ }^{41}$.

According to our observations, rhetorical figures are almost always indicators of the genre, because this concept is broader than the concept of stylistic figure or trope. This thesis, in the end, resonates with the position of A. Singaivska and S. Topachevsky, who believe that "the division of texts by genre is carried out taking into account the compositional and stylistic features" 42 , but "for the differentiation of genres can be important only one

37 Zazykin V. G. (1992). Psikhologiya $v$ reklame [Psychology in advertising]. Moscow: DataStrom (in Russian), p. 27.

38 Stankevich Yu. V. (2011). Movni suhestoheny $v$ tekstakh politychnoyi reklamy [Lingual suggestion categories in the political advertising texts] : (PhD Thesis), Odesa: Odesa I. I. Mechnikov National University, p. 8.

${ }^{39}$ Khlebnikova O. V. (2006). Semioticheskiye kody v filosofskom tekste [Semiotic codes in a philosophical text]. Bulletin of the Omsk State Pedagogical University (electronic journal), vol. 1, no. 13 Retrieved from:: http://www.omsk.edu/article/vestnikomgpu-11.pdf (accessed 3 May 2020).

${ }^{40}$ Ibid.

${ }^{41}$ Stepanov V. N. (2012). Semioticheskiye kody v reklamnom tekste [Semiotic codes in the advertising text]. Culture (electronic journal), vol. 13, no. 2. Retrieved from: www.culturalnet.ru/main/getfile/1813 (accessed 5 May 2020).

${ }^{42}$ Singaivska A. V. (2009). Problema reklamnykh zhanriv u konteksti normatyvnotekstual'noyi etyketyzatsiyi reklamnoho dyskursu [The problem of advertising genres in the context of normative-textual labeling of advertising discourse]. Language and Culture, vol. 126, p. 32-42. 
of the selected features" ${ }^{\prime 3}$. It is clear that the stylistic criterion is of particular relevance for determining the genre status of the advertising text by analyzing the rhetorical codes in it. To this end, we will rely on the conception of I. Imshynetska, in which the genre status of advertising text is determined by the goals of marketing activities, which can be sale and image $^{44}$. We will also add that the genre of advertising text will be qualified as a subcode of rhetorical code, and tropes and figures will consider their markers. After identifying the subcodes of rhetorical codes and their markers, we will determine the semiotic status of the latter based on Pierce's classification, where the leading role is played by the copy signs, index signs and symbol signs ${ }^{45}$. According to this classification the copy signs "indicates the object that it denotes" 46 , the index sign "refers to the object it denotes, based on the fact that it is really affected by this object" 47 , and the symbol signs "refers to the object designated by it by law - usually, associations of general ideas..., to force us to interpret the symbol as a reference to this object" 48 .

Thus, according to our observations, rhetorical codes have two subcodes:

1) subcode of sale advertising texts aimed at "stimulating the activity of buyers" ${ }^{\text {"49 }}$ It is represented by stylistic means that function in the language system of the texts themselves (excluding advertising slogans as their components), such as (in descending order):

- metaphor (over 380 cases): There are moments of pleasure, and there are moments of paradisal pleasure (chocolate "Baunty");

- repetition of words, phrases and sentences (over 345 cases): "Tide" with amplifier of purity and brightness gives brightness to both white and colored things (washing powder "Tide");

${ }^{43}$ Singaivska A. V. (2009). Problema reklamnykh zhanriv u konteksti normatyvnotekstual'noyi etyketyzatsiyi reklamnoho dyskursu [The problem of advertising genres in the context of normative-textual labeling of advertising discourse]. Language and Culture, vol. 126, p. 32-42.

44 Imshinetskaya I. A. (2007). Rechevoy stil' kommercheskoy reklamy v yeye zhanrovykh raznovidnostyakh [The speech style of commercial advertising in its genre variations] : (PhD Thesis), Perm: Perm State University, p. 9.

45 Selivanova O. O. (2008). Suchasna linhvistyka: napryamy ta problem [Modern linguistics: directions and problems]. Poltava: Environment. Kyiv (in Ukrainian), p. 124.

${ }^{46}$ Pierce Ch. S. (2000). Selected philosophical works. Moscow: Logos (in English), p. 185.

${ }^{47}$ Ibid., p. 186.

${ }^{48}$ Ibid.

49 Imshinetskaya I. A. (2007). Rechevoy stil' kommercheskoy reklamy v yeye zhanrovykh raznovidnostyakh [The speech style of commercial advertising in its genre variations] : (PhD Thesis), Perm: Perm State University, p. 14. 
- dubitation or "questions to the imaginary interlocutor, which serve to pose the problem and justify the form of reflection"50 (over 200 cases): Have you already experienced the first symptoms of allergies? Itching, tearing, red eyes, runny nose and nasal congestion, continuous sneezing? Do allergies affect your health and your life? "Edema" (drug "Edem");

- epithet (more than 190 cases): For each of them many surprises, unexpected impressions, delicious moments and incredible summer meetings (ketchup "Torchin");

- comparison (more than 70 cases): Ice cream "Hercules" is better than eggs, better than duck (ice cream "Hercules");

- hyperbole (over 65 cases): I have a superpower steam shock (iron "Tefal Anti Calc");

- rhyme (over 45 cases);

- personification (more than 15 cases): Black Friday has already arrived in Eldorado (shop "Eldorado").

The most common markers of this subcode are tropes (metaphors, epithets, comparisons, hyperboles, personifications). We include them in the category of symbol signs, because "their figurative means are incomprehensible" ${ }^{, 51}$. O. Brazgovska classifies metaphors as copy signs due to the presence in their structure of "two referents, between which similarity relations are established on a certain basis" ${ }^{25}$. We insist on the iconicsymbolic expression of metaphors, because in their tectonics there are socalled nonspecific nouns, "the semantic originality of which lies in the internal uncertainty of a set of reference and situational features of the

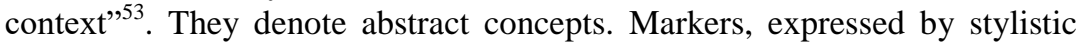
figures, we interpret as index signs. In some cases, they are instructions,

50 Bernadskaya Yu. S. (2008). Tekst v reklame [Text in advertising]. Moscow: UNITY-DANA (in Russian), p. 101.

51 Meshcheryakova N.V. (2012). Stilisticheskiye $i$ pragmalingvisticheskiye osobennosti reklamnykh tekstov sotsialnoy napravlennosti (na materiale tekstov sotsialnoy reklamy na russkom i nemetskom yazykakh) [Stylistic and pragmalinguistic features of social advertising texts (based on social Russian and German advertising texts) : (PhD Thesis), Moscow: Moscow State M. V. Lomonosov University, p. 13.

${ }^{52}$ Sokolova G. (2014). Vidy rechevogo vozdeystviya na kommunikanta [Types of speech impact on the communicant]. The word in the context of time. T. 1. Minsk: Belarusian State University, p. 388-392.

53 Kovalevska T. Yu. (2008). Komunikatyvni aspekty neyrolinhvistychnoho prohramuvannya [Communicative aspects of neurolinguistic programming]. Odesa: Astroprint. (in Ukrainian), p. 153. 
because "strengthen certain parts of the statement" they represent the relationship between the lexical components of the advertising text (dubitation and rhyme);

2) subcode of image advertising texts "fix in the minds of a wide range of people a positive image of the product or company... and usually have the form of a slogan" ${ }^{\natural 5}$. It has the following rhetorical means (in descending order):

- metaphor (over 130 cases): Touch of softness (trimmer "Veet Sensitive Precision");

- epithet (over 70 cases): The perfect combination of juice and tea flavors (tea "Lipton");

- hyperbole (more than 60 cases): Together we can do everything (bank "TasComBank");

- comparison (over 45 cases): "Comfy" is even steeper (store "Comfy");

- rhyme (more than 25 cases);

- play-on-words (over 20 cases): Phenomenally! No, mephenomenally! (drug "Mefenaminka");

- antithesis (more than 10 cases): One sauce - many recipes (sauce "Novaro").

It should be noted that in this subcode metaphors, epithets, hyperboles, comparisons, and rhymes have the same semiotic properties as the corresponding markers modeled in the previous subcode (see above). This is primarily due to their identical stylistic status. Antitheses, which are characteristic only for the subcode of image advertising texts, are index signs, because they are situational. They form the "stylistic basis of graduality" ${ }^{, 56}$ by contrasting the two phenomena, but out of context, each component of antonymous pairs loses such a semiotic rank, tending to the

${ }^{54}$ Terkulova D. R. (2004). Lingvostilisticheskiye i kommunikativno-pragmaticheskiye osobennosti angliyskogo reklamnogo teksta (na materiale tekstov reklamy delovykh uslug) [Linguostylistic, communicative and pragmatic features of the English advertising text (based on texts of advertising business services)] : (PhD Thesis), Moscow: Moscow State Pedagogical University, p. 136.

55 Imshinetskaya I. A. (2007). Rechevoy stil' kommercheskoy reklamy v yeye zhanrovykh raznovidnostyakh [The speech style of commercial advertising in its genre variations] : (PhD Thesis), Perm: Perm State University, p. 10.

${ }^{56}$ Terkulova D. R. (2004). Lingvostilisticheskiye i kommunikativno-pragmaticheskiye osobennosti angliyskogo reklamnogo teksta (na materiale tekstov reklamy delovykh uslug) [Linguostylistic, communicative and pragmatic features of the English advertising text (based on texts of advertising business services)] : (PhD Thesis), Moscow: Moscow State Pedagogical University, p. 136. 
paradigm of symbols. The play-on-words is in the form of symbol signs, because the play-on-words is "the process of creating new, virtual worlds with the help of language: by saying something, a person creates a special world that does not exist in reality"57. This operation is carried out arbitrarily, therefore the symbol signs have a high degree of arbitrary communication with the referent.

Thus, in both subcodes there are common markers, expressed primarily by metaphors, epithets, comparisons, rhymes and hyperboles, which have, however, different semiotic status. In turn, repetitions, dubitations and personifications are recorded only within the subcode of sales advertising texts, and the play-on-words and antitheses express the rhetoric of the subcode of image advertising texts.

\section{Vectors of rhetorical codes' influence in advertising}

To identify and describe the vectors of influence of rhetorical codes in advertising, we will take into account the relationship of suggestion with the mental functions of the human brain. These are the functions related to the control of attention (object for the suggerend are the words of the suggestor, his image, hypnogenic objects of concentration (audiovisual, tactile)); control of emotions (suggestor "infects" the suggerend or tries to cause the latter polar sensations and feelings); control of memory (the suggerend recalls various acts of previously experienced states or records in the mind or subconscious new suggested information $)^{58}$. We believe that taking into account the above data will provide a holistic view of the dynamics of the rhetorical codes as sensitizers of influential effects in advertising texts. We will also rely in part on the neurolinguistic Milton-model. According to T. Kovalevska, it is relevant precisely "for the identification of suggestive properties of language" ${ }^{59}$. Its influential mechanism "is based on the provisions of N. Khomsky's transformational grammar about the discrepancy between the deep structures of the message and their superficial

${ }^{57}$ Terkulova D. R. (2004). Lingvostilisticheskiye i kommunikativno-pragmaticheskiye osobennosti angliyskogo reklamnogo teksta (na materiale tekstov reklamy delovykh uslug) [Linguostylistic, communicative and pragmatic features of the English advertising text (based on texts of advertising business services)] : (PhD Thesis), Moscow: Moscow State Pedagogical University, p. 128.

58 Goncharov G. (2017). Suggestiya: teoriya i praktika. Velikaya sila gipnoza [Suggestion: theory and practice. The Great Power of Hypnosis]. Moscow: Publishing Solutions (in Russian), p. 46-47.

59 Kovalevska T. Yu. (2008). Komunikatyvni aspekty neyrolinhvistychnoho prohramuvannya [Communicative aspects of neurolinguistic programming]. Odesa: Astroprint. (in Ukrainian), p. 193. 
representations realized in speech, reflecting the processes of deletion, generalization and distortion of information described in NLP" ${ }^{\prime 60}$. The processes of deletion and generalization include universal quantifiers, modal operators of possibility / necessity, comparators of meaning, judgment, spectrum of nonspecific vocabulary, nominalization, and the processes of distortion include speech signatures ${ }^{61}$.

We present the results of this study:

1) in the subcode of sale advertising texts:

Metaphors often activate the NLP-process of deletion, because in their structure there are "nomenclature with a generalized reference index"62. We have in mind the non-specific nouns and nominalizations. Nonspecific nouns are the "semantically insufficient words in absolute usage" 63 (Discover all shades of taste of the perfect Nescafe coffee). Nominalizations are the "verb nouns, the using of which leads to a reduction of dynamics in verb semantics, resulting in significant semantic uncertainty of messages" 64 (for example, "Morshinskaya" from the reserved Morshinska sourses daily gives a natural renewal (mineral water "Morshinskaya"), where the selected nomen is used in its figurative sense. This same process, which provides semantic diffusion, but is already focused on "not on its neurological expansion, but on the darkening reduction of the comparison subject" update the comparison. For example: We change our look to be better for you (beer "Chernihiv"). In this context adjectives of the highest degree of

${ }^{60}$ Stankevich Yu. V. (2011). Movni suhestoheny $v$ tekstakh politychnoyi reklamy [Lingual suggestion categories in the political advertising texts] : (PhD Thesis), Odesa: Odesa I. I. Mechnikov National University, p. 7.

61 Kovalevskaya T. Yu. (2014). Milton-model yak suchasna neyrolinhvistychna tekhnolohiya doslidzhennya movlennyevoho vplyvu [Milton model as a modern neurolinguistic technology for the study of speech influence]. Odeska linhvistychna shkola: intehratsiya pidkhodiv [Odessa Linguistic School: integration of approaches]. Odesa: Publisher Bukaev Vadym Viktorovych, p. 346-358, p. 349.

62 Kovalevska T. Yu. (2008). Komunikatyvni aspekty neyrolinhvistychnoho prohramuvannya [Communicative aspects of neurolinguistic programming]. Odesa: Astroprint. (in Ukrainian), p. 223.

${ }^{63}$ Avdeenko I. A. (2001). Suggestivnyye svoystva verbalnykh sostavlyayushchikh reklamnogo teksta [Suggestive properties of the verbal components of the advertising text] : (PhD Thesis), Komsomolsk-na-Amur: Komsomolsk-na-Amur State Pedagogical University, p. 35.

${ }^{64}$ Stankevich Yu. V. (2011). Movni suhestoheny $v$ tekstakh politychnoyi reklamy [Lingual suggestion categories in the political advertising texts] : (PhD Thesis), Odesa: Odesa I. I. Mechnikov National University, p. 7.

65 Kovalevska T. Yu. (2008). Komunikatyvni aspekty neyrolinhvistychnoho prohramuvannya [Communicative aspects of neurolinguistic programming]. Odesa: Astroprint. (in Ukrainian), p. 223. 
comparison "provide either a complement (better than something), or a comparative contract predicative unit" $"$. We will add that their absence does not reduce their function of intensification of the advertising message. They maximize it.

Due to repetitions and rhymes "the automatism of perception of the message from the point of view of normal (entropic) distribution of phonological units and combinations, tokens, syntactic constructions is broken" ${ }^{67}$. Thus, with the help of repetitions (Wherever you go, your landscapes, your dances, your music are everywhere (beer "Baltika 7")) not only provides an increase in the memorability of the advertising message, but also achieves the effect of so-called the indirect suggestion. There is a deliberate duplication of the same information. Therefore the influence is no longer on the conscious, but on the subconscious component of the human psyche. In turn, rhyme is used to enhance the memorability of advertising text or its individual fragment, as well as to ensure the association and recognition of advertising among a variety of similar products.

Dubitation (Does your throat hurt? Do you feel constant discomfort? Try "Lizak"! (drug "Lizak")) is correlated with such a technique of the NLP-process of distortion, as reading thoughts. It is "a class of semantically incorrect surface structures, connected, first, with the speaker's conviction of what another person may know, think or feel, without having direct messages about it from this person, secondly, with the speaker's confidence that the other person knows what the speaker is thinking or feeling" ${ }^{\text {" }}$. These rhetorical techniques, according to Yu. Stankevich, "create the illusion of suggestor's awareness of the inner experiences, thoughts, feelings, intentions of the suggerend" 69 . However, we also emphasize their perception as hidden imperatives, because the relevant means are the tools of the so-called rhetorical strategy "problem - its solution".

Hyperboles indicate the connection with the process of generalization, "in which all elements or parts of the model of an individual break away

${ }^{66}$ Avdeenko I. A. (2001). Suggestivnyye svoystva verbalnykh sostavlyayushchikh reklamnogo teksta [Suggestive properties of the verbal components of the advertising text] : (PhD Thesis), Komsomolsk-na-Amur: Komsomolsk-na-Amur State Pedagogical University, p. 36.

${ }^{67}$ Ibid., p. 91.

${ }^{68}$ Kovalevska A. V. (2011). Metamodel linhvistychnoyi suhestyvnosti politychnykh reklamnykh slohaniv [Metamodel of political advertisement slogans' linguistic suggestion] : (PhD Thesis), Odesa: Odesa I. I. Mechnikov National University, p. 73.

69 Stankevich Yu. V. (2011). Movni suhestoheny $v$ tekstakh politychnoyi reklamy [Lingual suggestion categories in the political advertising texts] : (PhD Thesis), Odesa: Odesa I. I. Mechnikov National University, p. 8. 
from the original experience, which gave rise to these models, and begin to represent the whole category for which this experience is only a single case $^{\text {"70 }}$. First of all, we have in tropes in the structure of which there are universal quantifiers "lexicalized in the pronoun-adverbial paradigm and cause the destruction of local-temporal identification" ${ }^{, 71}$. For example: In your dreams everything is possible with the new "Danissimo Shake \& Go" (yogurt "Danissimo Shake \& Go").

Influence of other means from this subcode, namely epithets (Gentle bianco ice cream, crunchy Belgian chocolate, gourmet Italian cream fior de latte (ice cream "Impreza")) and personifications (The whole planet holds its breath (drink "Coca Cola")) we explain their focus on enhancing imagery in the advertising texts. Especially personification contributes to this effect, due to it "the advertising image is perceived more vividly"72. For example: A great helper in the kitchen is a superfunctional Phillips HD multicooker for a super price of UAH 2,499. The advertised product (multicooker "Phillips") in the text fragment is perceived as a person, because the primary meaning of the word helper is one who helps someone in something;

2) in the subcode of image advertising texts:

The trajectories of the influence of metaphors, epithets, hyperbole, comparisons, rhymes (their examples are in paragraph 2) coincide with the corresponding orientation of relevant markers recorded in the models of the subcode of sales advertising texts (see above). This is due to their identical rhetorical genesis and the same suggestions in the tectonics of the rhetorical figures and tropes. Because of this, only such rhetorical tools as play-onwords and antithesis need a more detailed analysis from the standpoint of suggestive linguistics and NLP in the subcode of image advertising texts.

Play-on-words is introduced into the advertising text in order to create a game effect, giving it novelty, originality, expressiveness, involvement of recipients in communication. This is confirmed in particular by the following example: Yogurt family menu (yogurt "Zhyvynka"), in which the rhetorical technique is mainly constructed on the basis of the reference

70 Kovalevska T. Yu. (2008). Komunikatyvni aspekty neyrolinhvistychnoho prohramuvannya [Communicative aspects of neurolinguistic programming]. Odesa: Astroprint. (in Ukrainian), p. 156.

Kovalevska T. (2012). Aktualni tekhnolohiyi stvorennya suhestyvnosti $v$ mediynykh dyskursakh [Actual technologies of creating suggestibility in media discourses]. Intercultural communication: problems and prospects, vol. 1, p. 194-200, p. 197.

${ }^{72}$ Livshits T. N. (1999). Spetsifika reklamy v pragmaticheskom i lingvisticheskom aspektakh [Specificity of advertising in the pragmatic and linguistic aspects] : (PhD Thesis), Taganrog: Taganrog State Pedagogical Institute, p. 155. 
affiliation of the advertised product / service: yogurt - yogurt (formed from the noun "yogurt" first by forming a verb without do or make, and then its forms of the imperative mood). In addition, there are cases of relevant rhetorical formations with a pragmatonymic origin: Let be prom (site "Prom.ua"). We see their suggestive potential in the fact that they have the ability to violate the logic of perception through a pronounced game nature and transfer meaning, because "the recipient by engaging in the game receives positive emotions" ${ }^{, 73}$. These units have a right hemisphere orientation.

The antithesis serves as a rhetorical technique "to design the selection, emphasize the statement and the idea of the uniqueness of each specific advertising offer (promise) and each specific activity of the company"74. For example: Less doubt - more pleasure (drug "Eroton"). Therefore, the antonymous pairs of words in the slogans have "high persuasive potential, as they are associated with the representation of the advertised object as changing the world, demonstrating the situation before and after and proof through comparison" ${ }^{, 75}$. We also insist on the ability of the antithesis to accelerate the mnemonic fixation of information in the minds of advertising recipients, because, as the results of research by I. Cherepanova show, "the less similarity between the meanings of comparable words, the easier it is to blur their boundaries" ${ }^{\prime 76}$, primarily semantic. This causes the strengthening of suggestive effects.

Thus, rhetorical codes illustrate not only the stylistic diversity in advertising texts, but also outline their powerful suggestibility, because in both subcodes there are tools of semantic scattering, expressiveness,

73 Samarina V. V. (2010). Nimetskomovnyy reklamnyy dyskurs: prahmatychnyy, kohnityvnyy ta linhvostylistychnyy aspekty [German-language advertising discourse: pragmatic, cognitive and linguistic-stylistic aspects] : (PhD Thesis), Kharkov: Kharkov National M. Kazarin University, p. 12.

${ }^{74}$ Terkulova D. R. (2004). Lingvostilisticheskiye i kommunikativno-pragmaticheskiye osobennosti angliyskogo reklamnogo teksta (na materiale tekstov reklamy delovykh uslug) [Linguostylistic, communicative and pragmatic features of the English advertising text (based on texts of advertising business services)] : (PhD Thesis), Moscow: Moscow State Pedagogical University, p. 120.

75 Semenyuk T. P. (2017). Kohnityvno-semantychni ta prahmatychni osoblyvosti nimetskomovnykh polikodovykh tekstiv (na materiali komertsiynoyi reklamy) [Cognitive, semantic and pragmatic peculiarities of German polycode texts (based on commercial advertising)] : (PhD Thesis), Lutsk - Zaporozhzhya: Lesya Ukrainka Eastern European National University; Zaporizhzhya National University, p. 185.

76 Cherepanova I. Yu. (1999). Dom kolduni. Yazyk tvorcheskogo bessoznatelnogo [House of the witch. The language of creative Unconscious]. Moscow: "KSP +" (in Russian), p. 175. 
multiple duplication of information, imagery, etc., which have a hemispherical orientation.

\section{CONCLUSIONS}

Many scientific objectifications of the phenomenon of influence, primarily communicative, confirm the paramount role and powerful effectiveness of methods of suggestive linguistics and neurolinguistic programming in relevant observations,. At the same time, this testifies to the prospects of this aspect for linguosemiotic research. The origin and the current status of the scientific explanation of the communicative influence are also considered and a number of vague discussion views are especially indicated. Among the types of communicative influence, suggestion in the content of Ukrainian commercial television advertising is its basic mechanism, which involves blocking rational (critical) thinking during the perception of information and differs from manipulation primarily by the purpose.

We considered the rhetorical code as the linguosemiotic code, which consists of two subcode (according to V. Stepanov's classification). We first identified its markers, which are stylistic figures and tropes. Then we determine the semiotic status of the fixed markers (according to Ch. Pearce's classification). The last action is the describing of their influential (suggestive) potential.

The rhetorical code is represented by the subcode of sale advertising texts and subcode of image advertising texts in which the metaphor has the dominant positions.

It is worth noting that within the subcode of sales advertising texts all tropes are symbol sings, and rhetorical figures are index signs. But in the block of image advertising texts this trend is characteristic only for tropes, because the figures are expressed as index signs (antitheses) and symbol sings (play-on-words).

In the subcodes of rhetorical codes many markers are aimed at launching neuro-linguistic processes of deletion, distortion and generalization. The processes of deletion are provided mainly by metaphors and comparison short circuits, processes of distortion are by dubitation, and processes of generalization are by hyperboles.

\section{SUMMARY}

The article is devoted to the problem of determining the influential rhetorical codes potential in the texts of Ukrainian commercial television advertising in which they are linguosemiotic elements. The author of the article revealed the essence of such concepts as "influence", "communicative 
influence", "rhetorical code". The mechanism of suggestive influence is described in detail, because suggestion is relevant for commercial advertising.

The author determined that the rhetoric of advertising is determined by two subcodes that have similar and different markers (stylistic figures and tropes). These markers have different semiotic status, but mostly symbolic.

The author described the influential vectors of the most relevant rhetorical advertising codes and drew attention to the fact that their influence is associated with the generation of NLP processes.

\section{REFERENCES}

1. Alekseeva M. S. (2009). Pretsendentnyye fenomeny $v$ internetreklame predpriyatiy restorannogo biznesa [Precedent phenomena in the Internet advertising of restaurant business enterprises] : ( $\mathrm{PhD}$ Thesis), Nizhny Tagil: Nizhny Tagil State Pedagogical University.

2. Avdeenko I. A. (2001). Suggestivnyye svoystva verbalnykh sostavlyayushchikh reklamnogo teksta [Suggestive properties of the verbal components of the advertising text] : (PhD Thesis), Komsomolsk-na-Amur: Komsomolsk-na-Amur State Pedagogical University.

3. Ball G. A., Burgin M. S. (1994). Analiz psikhologicheskikh vozdeystviy i yego pedagogicheskoye znacheniye [Analysis of psychological influences and its pedagogical significance]. Psychology, no. 4 , pp. $56-66$.

4. Bernadskaya Yu. S. (2008). Tekst v reklame [Text in advertising]. Moscow: UNITY-DANA (in Russian).

5. Bilodid I. K. (1980). Slovnyk ukrayinskoyi movy [Dictionary of the Ukrainian language]. Kyiv: Naukova Dumka.

6. Cherepanova I. Yu. (1999). Dom kolduni. Yazyk tvorcheskogo bessoznatelnogo [House of the witch. The language of creative Unconscious]. Moscow: "KSP +" (in Russian).

7. Dzyaloshinsky I. M. (2012). Kommunikativnoye vozdeystviye: misheni, strategii, tekhnologii [Communicative impact: targets, strategies, technologies]. M. : HSE (in Russian).

8. Goddard A. (1998). The Language of Advertising. London - New York: Routledge (in English).

9. Goncharov G. (2017). Suggestiya: teoriya i praktika. Velikaya sila gipnoza [Suggestion: theory and practice. The Great Power of Hypnosis]. Moscow: Publishing Solutions (in Russian).

10. Imshinetskaya I. A. (2007). Rechevoy stil' kommercheskoy reklamy v yeye zhanrovykh raznovidnostyakh [The speech style of commercial advertising in its genre variations] : (PhD Thesis), Perm: Perm State University. 
11. Issers O.S. (2011). Rechevoye vozdeystviye [Speech influence]. Moscow: Flint: Science (in Russian).

12. Khlebnikova O. V. (2006). Semioticheskiye kody v filosofskom tekste [Semiotic codes in a philosophical text]. Bulletin of the Omsk State Pedagogical University (electronic journal), vol. 1, no. 13 Retrieved from:: http://www.omsk.edu/article/vestnik-omgpu-11.pdf (accessed 3 May 2020).

13. Kovalevska A. V. (2011). Metamodel linhvistychnoyi suhestyvnosti politychnykh reklamnykh slohaniv [Metamodel of political advertisement slogans' linguistic suggestion] : (PhD Thesis), Odesa: Odesa I. I. Mechnikov National University.

14. Kovalevska A. V. (2017). Suhestiya ta suhestyvni teksty: vytoky i spetsyfika [Suggestion and suggestive texts: origins and specifics]. Odeska linhvistychna shkola: u prostorakh interpretatsiy [Odessa Linguistic School: in the spaces of interpretations]. Odessa: PolyPrint, pp. 239-247.

15. Kovalevska T. (2012). Aktualni tekhnolohiyi stvorennya suhestyvnosti $\mathrm{v}$ mediynykh dyskursakh [Actual technologies of creating suggestibility in media discourses]. Intercultural communication: problems and prospects, vol. 1, pp. 194-200.

16. Kovalevska T. Yu. (2008). Komunikatyvni aspekty neyrolinhvistychnoho prohramuvannya [Communicative aspects of neurolinguistic programming]. Odesa: Astroprint. (in Ukrainian).

17. Kovalevska T. Yu. (2014). Aktualni napryamy doslidzhennya verbalnoyi suhestiyi [Actual directions of research of verbal suggestion]. Odeska linhvistychna shkola: $u$ intehratsiya pidkhodiv [Odessa Linguistic School: integration of approaches]. Odesa: Publisher Bukaev Vadym Viktorovych, pp. 323-331.

18. Kovalevskaya T. Yu. (2014). Milton-model yak suchasna neyrolinhvistychna tekhnolohiya doslidzhennya movlennyevoho vplyvu [Milton model as a modern neurolinguistic technology for the study of speech influence]. Odeska linhvistychna shkola: intehratsiya pidkhodiv [Odessa Linguistic School: integration of approaches]. Odesa: Publisher Bukaev Vadym Viktorovych, pp. 346-358.

19. Kuzmin O., Kolinko N. (2013). Metody vplyvu yak efektyvnyy instrument kerivnoyi innovatsiynoyi [Methods of influence as an effective tool of leading innovative activity] Visnyk of Ternopil National University of Economics, vol. 2, pp. 71-80.

20. Livshits T. N. (1999). Spetsifika reklamy $v$ pragmaticheskom $i$ lingvisticheskom aspektakh [Specificity of advertising in the pragmatic and linguistic aspects] : (PhD Thesis), Taganrog: Taganrog State Pedagogical Institute. 
21. Meshcheryakova N. V. (2012). Stilisticheskiye $i$ pragmalingvisticheskiye osobennosti reklamnykh tekstov sotsialnoy napravlennosti (na materiale tekstov sotsialnoy reklamy na russkom i nemetskom yazykakh) [Stylistic and pragmalinguistic features of social advertising texts (based on social Russian and German advertising texts) : (PhD Thesis), Moscow: Moscow State M. V. Lomonosov University.

22. Navasartyan L. G. (2017). Yazykovyye sredstva i rechevyye priyemy manipulyatsii informatsiyey $v$ SMI (na materiale rossiyskikh gazet) [Language tools and speech techniques for manipulating information in the media (based on Russian newspapers)] : (PhD Thesis), Saratov: Saratov State University.

23. Petryk B. M. (2011). Suhestyvni tekhnolohiyi manipulyatyvnoho vplyvu [Suggestive technologies of manipulative influence]. Kyiv: CJSC "VIPOL" (in Ukrainian).

24. Pierce Ch. S. (2000). Selected philosophical works. Moscow: Logos (in English).

25. Samarina V. V. (2010). Nimetskomovnyy reklamnyy dyskurs: prahmatychnyy, kohnityvnyy ta linhvostylistychnyy aspekty [Germanlanguage advertising discourse: pragmatic, cognitive and linguistic-stylistic aspects] : (PhD Thesis), Kharkov: Kharkov National M. Kazarin University.

26. Selivanova O. O. (2008). Suchasna linhvistyka: napryamy ta problem [Modern linguistics: directions and problems]. Poltava: Environment. Kyiv (in Ukrainian).

27. Semenyuk T. P. (2017). Kohnityvno-semantychni ta prahmatychni osoblyvosti nimetskomovnykh polikodovykh tekstiv (na materiali komertsiynoyi reklamy) [Cognitive, semantic and pragmatic peculiarities of German polycode texts (based on commercial advertising)] : (PhD Thesis), Lutsk - Zaporozhzhya: Lesya Ukrainka Eastern European National University; Zaporizhzhya National University.

28. Shelestyuk E. V. (2014). Rechevoye vozdeystviye: ontologiya $i$ metodologiya issledovaniya [Speech influence: ontology and research methodology]. Moscow: FLINT: Nauka (in Russian).

29. Singaivska A. V. (2009). Problema reklamnykh zhanriv u konteksti normatyvno-tekstual'noyi etyketyzatsiyi reklamnoho dyskursu [The problem of advertising genres in the context of normative-textual labeling of advertising discourse]. Language and Culture, vol. 126, pp. 32-42.

30. Skibiltsa L. I. (2009). Liderstvo ta styl roboty menedzhera [Leadership and style of work of the manager]. Kyiv: Knyha (in Ukrainian).

31. Sokolova G. (2014). Vidy rechevogo vozdeystviya na kommunikanta [Types of speech impact on the communicant]. The word in the context of time. T. 1. Minsk: Belarusian State University, pp. 388-392. 
32. Stankevich Yu. V. (2011). Movni suhestoheny v tekstakh politychnoyi reklamy [Lingual suggestion categories in the political advertising texts] : (PhD Thesis), Odesa: Odesa I. I. Mechnikov National University.

33. Stepanov V. N. (2012). Semioticheskiye kody v reklamnom tekste [Semiotic codes in the advertising text]. Culture (electronic journal), vol. 13, no. 2. Retrieved from: www.culturalnet.ru/main/getfile/1813 (accessed 5 May 2020).

34. Sternin I. A. (2015). Osnovy rechevogo vozdeystviya [Fundamentals of speech influence]. Moscow - Berlin: Direct Media (in Russian).

35. Terkulova D. R. (2004). Lingvostilisticheskiye $i$ kommunikativnopragmaticheskiye osobennosti angliyskogo reklamnogo teksta (na materiale tekstov reklamy delovykh uslug) [Linguostylistic, communicative and pragmatic features of the English advertising text (based on texts of advertising business services)] : (PhD Thesis), Moscow: Moscow State Pedagogical University.

36. Tolkunova E. G. (1998). Semanticheskoye opisaniye sovremennykh russkikh reklamnykh tekstov (suggestologicheskiy aspekt) [The semantic description of modern Russian advertising texts (suggestological aspect)] : (PhD Thesis), Barnaul: Barnaul State University.

37.Zazykin V. G. (1992). Psikhologiya $v$ reklame [Psychology in advertising]. Moscow: DataStrom (in Russian).

38. Zirka V. V. (2005). Yazykovaya paradigma manipulyativnoy igry $v$ reklame [The language paradigm of a manipulative play in advertising] : (Doctor Thesis), Dnepropetrovsk: Dnepropetrovsk National University.

Information about the author: Shcherbak O. V.,

$\mathrm{PhD}$ in Philology, Senior Lecturer, Department of Applied Linguistics, Admiral Makarov National University of Shipbuilding 9, Heroes of Ukraine Avenue, Mykolaiv, 54025, Ukraine ORCID: orcid.org/0000-0003-3097-7878 